\title{
PENYEMBUHAN LUKA BAKAR PADA TIKUS PUTIH DENGAN MENGGUNAKAN EKSTRAK DAUN PEGAGAN (CENTELLA ASIATICA) $25 \%$ DAN EKSTRAK DAUN PETAI CINA (LEUCAENA LEUCOCEPHALA) 30\%
}

\author{
Syaifuddin Kurnianto ${ }^{1)}$, Kusnanto ${ }^{2)}$, Padoli $^{3)}$ \\ 1) Magister Keperawatan Fakultas Keperawatan Universitas Airlangga \\ Email: syaifuddin.akper.lumajang@ gmail.com \\ 2) Fakultas Keperawatan Universitas Airlangga \\ 3) Poltekkes Kemenkes Surabaya
}

\begin{abstract}
Burns are one of the injuries that require the best care to achieve optimal cure. Several previous studies have suggested that leaf extract of Centella asiatica and chinese petai leaf potential as burning healing agent for mild and moderate degree besides medical treatment. The purpose of this study was to explain the difference of effectiveness of leaf extract of pegagan leaves $25 \%$ by giving $30 \%$ petai chinese extract to heal burns. The samples were white rats (Rattus norvegicus) with total of 28 tails selected according to inclusion criteria then divided into 4 groups randomly is group of leaf extract of pegagan leaf $25 \%$ (K1), 30\% petai petroleum extract (K2) Gel base (K3) and control (K4). The design of this study used the randomized posttest only control group design and analyzed using Anova and post Hoc Duncan test. The measured variable is the duration of wound healing. Anova test results and Post Hoc Duncan test duration of burn wound healing show that 30\% Chinese petai extract group has significant difference with other group with $\mathrm{p}$-value $<0,05$. Treatment of burns by using chinese petroleum extract $30 \%$ more effective than $25 \%$ of pegagan leaf extract in healing burns in white rats (Rattus norvegicus) as evidenced by the fastest healing time of burns
\end{abstract}

Keywords: Chinese petai, pegagan leaf, burns healing

\begin{abstract}
Abstrak: Luka bakar merupakan salah satu cidera yang memerlukan perawatan terbaik untuk mencapai derajat kesembuhan yang optimal. Beberapa penelitian terdahulu menjelaskan bahwa ekstrak daun pegagan dan daun petai cina potensial sebagai agen penyembuhan luka bakar untuk derajat ringan dan sedang disamping pengobatan medis. Tujuan penelitian ini adalah untuk menjelaskan perbedaan efektifitas pemberian ekstrak daun pegagan 25\% dengan pemberian ekstrak daun petai cina $30 \%$ terhadap penyembuhan luka bakar. Sampel penelitian adalah tikus putih (Rattus norvegicus) dengan jumlah 28 ekor yang dipilih sesuai kriteria inklusi kemudian dibagi menjadi 4 kelompok secara random yaitu: kelompok pemberian ekstrak daun pegagan $25 \%$ (K1), kelompok pemberian ekstrak daun petai cina 30\% (K2), kelompok pemberian basis gel (K3) dan kontrol (K4). Desain penelitian ini menggunakan the randomized post test only control group design dan dianalisis menggunakan uji Anova dan post Hoc Duncan. Variabel yang diukur yaitu lama waktu penyembuhan luka. Hasil uji Anova dan uji Post Hoc Duncan lama waktu penyembuhan luka bakar menunjukkan bahwa kelompok ekstrak petai cina 30\% memiliki perbedaan yang signifikan dengan kelompok lainnya dengan nilai $p$-value $<0,05$. Pengobatan luka bakar dengan menggunakan ekstrak daun petai cina $30 \%$ lebih efektif daripada ekstrak daun pegagan 25\% dalam penyembuhan luka bakar pada tikus putih (Rattus norvegicus) yang dibuktikan dengan waktu penyembuhan luka bakar yang paling cepat.
\end{abstract}

Kata kunci: petai cina, daun pegagan, penyembuhan luka bakar. 


\section{PENDAHULUAN}

Infeksi luka bakar menjadi masalah serius karena menyebabkan keterlambatan dalam pematangan epidermis dan menyebabkan pembentukan jaringan parut (Church et al., 2006). Gomez et al., (2009) menjelaskan bahwa infeksi menjadi penyebab umum dari morbiditas dan mortalitas pada penderita luka bakar. Hal ini dikarenakan pertumbuhan bakteri pada permukaan luka bakar dikontrol tetapi tidak diberantas (Church et al., 2006). Perawatan luka bakar dengan menggunakan rejimen salep antimikroba seperti silver sulfadiazine, mafenide, silver nitrat, povidone-iodine, mupirocin dan bacitracin, digunakan untuk mengurangi risiko infeksi pada luka ringan dan luka bakar. Namun, antimikroba topikal tersebut memiliki beberapa efek samping dan hanya sebagian efektif dalam penyembuhan luka (Somboonwong et al., 2012).

Luka bakar merupakan salah satu cidera yang dapat mengenai siapa saja. Diperkirakan satu dari sekitar 3,5 juta orang akan mengalami luka bakar (Sheridan, 2012). World Health Organization (WHO) memperkirakan bahwa terdapat 265.000 kematian yang terjadi setiap tahunnya di seluruh dunia akibat luka bakar (WHO, 2014). Di Indonesia, prevalensi luka bakar pada tahun 2013 adalah sebesar $0.7 \%$ dan telah mengalami penurunan sebesar $1.5 \%$ dibandingkan pada tahun 2008 (2.2\%). Provinsi dengan prevalensi tertinggi adalah Papua (2.0\%) dan Bangka Belitung (1.4\%), sedangkan prevalensi di Jawa Timur sebesar 0.7\% (Depkes, 2013).

Sejumlah studi menunjukkan bahwa tanaman tradisional potensial sebagai agen penyembuhan luka disamping pengobatan medis untuk luka bakar ringan-sedang (Lin et al., 2010). Sebuah studi tentang aktivitas penyembuhan luka dari beberapa jenis ekstrak berbeda Centella asiatica pada luka insisi dan luka bakar menjelaskan bahwa penggunaan ekstrak dari Centella asiatica sangat menunjang proses penyembuhan luka melalui mekanisme penghambatan inflamasi, menginduksi sintesis kolagen, menstimulasi pembentukan pembuluh darah baru, menginduksi vasodilatasi serta mengurangi stres oksidatif pada luka (Somboonwong et al., 2012).

Studi terkait efektivitas daun petai cina (Leucaena leucocephala) dan daun jarak pagar (Jatropha curcas) terhadap proses penyembuhan luka bakar grade II pada tikus putih (Rattus norvegicus) membuktikan bahwa daun petai cina (Leucaena leucocephala) lebih efektif digunakan sebagai alternatif penyembuhan luka bakar derajat II dari pada daun jarak pagar (Jatropha curcas) (Rohmah et al., 2016). Studi lain yang meneliti terkait formulasi dan uji aktivitas gel ekstrak daun petai cina sebagai sediaan obat luka bakar membuktikan bahwa semakin tinggi konsentrasi gel ekstrak daun petai cina maka akan semakin luas daya sebarnya, semakin baik daya penyembuhan luka dan mempersingkat daya lekatnya (Dewantari dan Suhartini, 2015).

Pegagan mengandung senyawa glikosida triterpenoida yang disebut saponin, mengandung asiaticoside yang berperan dalam penyembuhan luka. Kandungan zat ini paling banyak terdapat pada daun (Widianingtyas et al., 2014). Asiaticoside yang dipajankan pada luka akan menstimulasi produksi kolagen 1 pada sel kulit fibroblas manusia. Kolagen inilah yang nantinya memegang peranan dalam penyembuhan luka. Selain itu, asiaticoside dapat meningkatkan kandungan antioksidan yang juga menunjang penyembuhan luka (Somboonwong et al., 2012). Asiaticoside juga menstimulasi percepatan pembentukan epidermis melalui percepatan proses cicatricial tanpa harus membentuk jaringan scar pada bekas luka dikarenakan asiaticoside mampu melakukan proses penghambatan fase inflamasi pada hipertrofi scar dan keloid (Bhavna and Jyoti, 2011).

Daun petai cina mengandung zat aktif alkaloid, saponin, flavonoid, lektin dan tanin. Berbagai kandungan yang terdapat 
dalam daun petai cina diperkirakan sebagai antiinflamasi dan antioksidan adalah flavonoid. Aktivitas antiinflamasi flavonoid melalui penghambatan siklooksigenase dan lipooksigenase menyebabkan terjadi pembatasan jumlah sel inflamasi yang bermigrasi ke jaringan perlukaan sehingga reaksi inflamasi akan berlangsung lebih singkat dan kemampuan proliferatif dari TGF- $\beta$ tidak terhambat. Proses ini mengakibatkan fase proliferasi dapat segera terjadi. Kandungan lektin berfungsi menstimulasi pertumbuhan sel kulit. Kandungan saponin dan tannin dalam petai cina dapat merangsang terjadinya angiogenesis (Rahmawati, 2014; Dewantari and Sugihartini, 2015). Saponin juga dapat merangsang pembentukan sel epitel baru dan mendukung proses epitelisasi sehingga dapat menyebabkan pengecilan ukuran luka bakar (Widyantoro dan Sugihartini, 2015). Selain itu, saponin dapat memacu pertumbuhan kolagen dalam proses penyembuhan luka (Igbinosa and Aiyegoro, 2009). Diharapakan dengan adanya manfaat kandungan dalam ekstrak daun pegagan dan daun petai cina penyembuhan luka bakar dapat berlangsung lebih cepat.

\section{METODE}

Rancangan penelitian ini merupakan jenis true experiment, dengan desain penelitian the randomized post test only control group design. Pada rancangan ini menggunakan sampel tikus putih (Rattus norvegicus) yang telah disesuaikan dengan kriteria inklusi yang ditetapkan yaitu: galur Sprague dawley; usia yang sama yaitu \pm 3 sampai dengan 4 bulan; berat badan 150 200 gram; Jenis kelamin yang sama yaitu jantan; dalam kondisi sehat ditandai dengan gerakannya aktif dan tidak menyendiri di sudut kandang, bulu bersih dan halus, mata jernih, tidak mengeluarkan cairan abnormal dari mata, telinga, anus dan tanpa ada kecacatan serta tidak mengalami penyusutan BB hingga $10 \%$ pada masa aklimatisasi; dan diinduksi luka bakar derajat II dangkal. Jumlah sampel berjumlah 28 ekor yang dihitung berdasarkan rumus Federer dan dibagi menjadi empat kelompok dengan menggunakan teknik random sampling. Kelompok K1 akan mendapatkan perlakuan perawatan luka bakar dengan menggunakan ekstrak daun pegagan $25 \%$ dalam bentuk gel sebanyak $100 \mathrm{mg} 1 \mathrm{kali}$ oles setiap hari hingga luka bakar sembuh. Kelompok K2 akan mendapatkan perlakuan perawatan luka bakar dengan menggunakan ekstrak daun petai cina $30 \%$ dalam bentuk gel sebanyak $100 \mathrm{mg} 1 \mathrm{kali}$ oles setiap hari hingga luka bakar sembuh. Kelompok K3 akan mendapatkan perlakuan perawatan luka dengan menggunakan basis gel sebanyak $100 \mathrm{mg} 1$ kali oles setiap hari hingga luka bakar sembuh. Kelompok K4 tanpa diberikan perlakuan. Penelitian ini bertujuan untuk mengetahui efektivitas ekstrak daun pegagan (Centella asiatica) $25 \%$ dengan ekstrak daun petai cina (Leucaena leucocephala) 30\% terhadap penyembuhan luka bakar pada tikus putih (Rattus norvegicus).

Pada penelitian ini dilakukan 2 jenis analisis data yaitu analisis data deskriptif dengan menggambarkan data secara ilmiah dalam bentuk tabel atau grafik. Sedangkan analisis data yang kedua yakni peneliti melakukan analisis inferensial yang meliputi uji oneway Anova, uji Post Hoc dengan uji Duncan. Untuk mendapatkan hasil analisis yang valid, maka dalam melakukan analisis inferensial ini peneliti menggunakan bantuan software SPSS. Hasil dari analisis inferensial ini akan digunakan oleh peneliti untuk membuktikan signifikasi atau tidaknya hipotesis yang telah peneliti tetapkan.

\section{HASIL \& PEMBAHASAN}

\section{a. Hasil}

Penelitian ini menggunakan ekstrak daun pegagan $25 \%$ dan daun petai cina $30 \%$ yang dibuat di UPT Materia Medica Batu Dinas Kesehatan Pemerintah Provinsi 
Jawa Timur. Bahan dasar daun pegagan dan daun petai cina diperoleh dari hasil budidaya kebun UPT Materia Medica Batu-Malang. Serbuk daun pegagan dengan berat 500 gram diekstraksi menggunakan pelarut etanol $96 \%$ sejumlah 4,5 liter dihasilkan ekstrak sejumlah $65 \mathrm{ml}$ serta dari 500 gram serbuk daun petai cina yang diekstraksi dengan menggunakan pelarut etanol $96 \%$ sejumlah 4,5 liter dihasilkan ekstrak sebanyak $45 \mathrm{ml}$. Hasil ekstrak daun pegagan dan daun petai cina dijadikan sediaan gel dengan konsentrasi gel ekstrak pegagan 25\% dan gel ekstrak daun petai cina $30 \%$ dengan berat masingmasing 50 gram.

Gambaran data hasil penelitian ini dapat dilihat pada gambar diagram 1 di bawah ini.

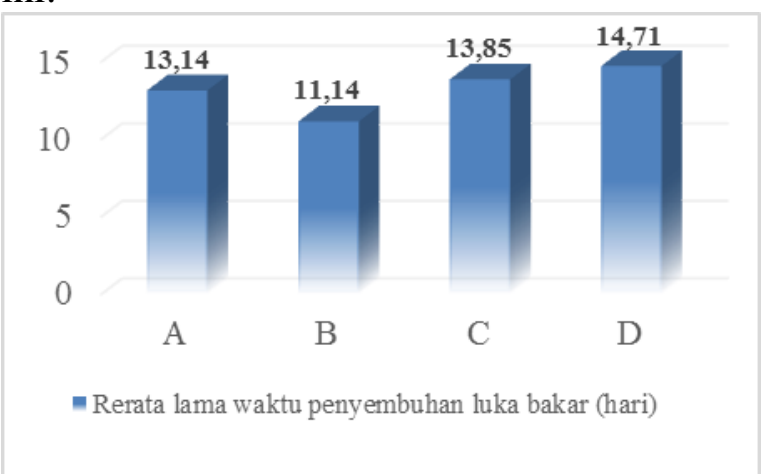

Gambar 1 Data rerata lama waktu penyembuhan luka bakar (hari)

Gambar 1 menunjukkan bahwa rerata lama waktu penyembuhan luka bakar yang terlama terdapat pada kelompok kontrol dengan rerata $14,71 \pm 1,60$ hari dan rerata lama waktu penyembuhan luka bakar yang paling cepat terdapat pada kelompok ekstrak daun petai cina $30 \%$ dengan rerata $11,14 \pm 0,89$ hari. Rerata lama waktu penyembuhan luka pada masing-masing kelompok perlu diuji normalitas dan homogenitas variannya terlebih dahulu sebagai syarat pemenuhan asumsi uji Anova dan uji Post Hoc Duncan. Uji normalitas menggunakan uji Shapiro Wilk dan uji homogenitas varian dengan menggunakan uji Lavenne. Hasil uji normalitas dan homogenitas varian menunjukkan nilai $p$-value $>0,05$ yang berarti data berdistribusi normal dan mempunyai varian yang homogen.

Uji Anova dan Post Hoc Duncan untuk mengetahui perbandingan rerata antar kelompok dan perbedaan bermakna antar kelompok digambarkan pada Tabel 1 di bawah.

Table 1 Hasil uji Anova dan Post Hoc Duncan

\begin{tabular}{cccc}
\hline Variable & Group & $\begin{array}{c}\text { ANOVA } \\
\text { sig. }\end{array}$ & $\begin{array}{c}\text { Post Hoc Test } \\
\text { Duncan }\end{array}$ \\
\hline Lama & K1 & & $13,14^{\mathrm{b}} \pm 1,06$ \\
Waktu & $\mathrm{K} 2$ & 0,001 & $11,4^{\mathrm{a}} \pm 0,89$ \\
Penyembu & $\mathrm{K} 3$ & & $13,85^{\mathrm{bc}} \pm 0,89$ \\
han Luka & $\mathrm{K} 4$ & & $14,71^{\mathrm{c}} \pm 1,60$ \\
\hline
\end{tabular}

Keterangan:

* Notasi alfabetis ${ }^{\mathrm{a}, \mathrm{b}, \mathrm{c}}$ superskrip yang berbeda pada kolom yang sama menunjukkan perbedaan yang bermakna berdasarkan uji Duncan.

Berdasarkan tabel 1 dapat diketahui bahwa hasil uji ANOVA pada variabel lama waktu penyembuhan luka mempunyai nilai $p$-value $<0,05$ yang berarti terdapat perbedaan lama waktu penyembuhan luka bakar pada kelompok perlakuan dan kontrol. Hasil uji Duncan pada variabel lama waktu penyembuhan luka menunjukkan bahwa kelompok ekstrak daun petai cina $30 \%$ mempunyai perbedaan secara bermakna dengan kelompok yang lainnya. Kelompok ekstrak daun pegagan $25 \%$ dan basis gel tidak mempunyai perbedaan secara bermakna, namun kelompok ekstrak daun pegagan $25 \%$ mempunyai perbedaan secara bermakna dengan kelompok kontrol. Kelompok basis gel dan kontrol tidak mempunyai perbedaan secara bermakna. Dengan demikian penggunaan ekstrak daun petai cina $30 \%$ memberikan dampak perbedaan secara bermakna terhadap lama waktu penyembuhan luka bakar daripada penggunaan ekstrak daun pegagan $25 \%$.

\section{b. Pembahasan}

Berdasarkan kajian literatur dijelaskan bahwa lama penyembuhan luka bakar superficial partial thickness dapat sembuh kurang lebih 14-21 hari (Moenadjat, 2009; Majid dan Prayogi, 2013). Hasil penelitian 
yang dilakukan Rohmah et al. (2016) menunjukkan bahwa rata-rata penyembuhan luka bakar derajat II menggunakan ekstrak kasar daun petai cina membutuhkan waktu 12,78 hari, lebih cepat 2 hari daripada kelompok perlakuan lain. Hasil penelitian Widianingtyas et al. (2014) menunjukkan lama penyembuhan luka bakar derajat II dangkal pada kelompok ekstrak daun pegagan $25 \%$ adalah 10,8 $\pm 0,84$ hari lebih cepat dibandingkan dengan kelompok perlakuan yang lain.

Menurut peneliti, hasil penelitian yang telah didapat sesuai dengan tinjauan teori yang telah ada bahwa pemberian ekstrak daun pegagan $25 \%$ dan ekstrak daun petai cina $30 \%$ memberikan pengaruh pada penyembuhan luka bakar tikus putih daripada kelompok kontrol yang sembuh secara alami, namun pada penelitian ini luka bakar yang diberikan perawatan luka menggunakan ekstrak daun petai cina $30 \%$ ebih cepat mengalami penyembuhan daripada yang diberikan perawatan luka dengan menggunakan ekstrak daun pegagan $25 \%$. Percepatan penyembuhan luka bakar pada kelompok ekstrak daun petai cina $30 \%$ terjadi dikarenakan dikarenakan pada ekstrak daun petai cina $30 \%$ mengandung tiga metabolit sekunder yaitu flavonoid, tanin dan saponin (Widiyantoro dan Sugihartini, 2015), sedangkan ekstrak daun pegagan $25 \%$ mengandung flavonoid dan saponin (Sugianto, et al., 2013). Flavonoid bersifat sebagai antibakteri dan antioksidan yang dapat meningkatkan proses penyembuhan luka (Haryani et al., 2012; Naibaho et al., 2013). Tanin dapat berpengaruh terhadap penyembuhan luka dengan beberapa mekanisme seluler diantaranya adalah meningkatkan pembentukan kembali jaringan dermis pada jaringan luka (fibroplasia) (Sheikh, et al., 2011). Sedangkan saponin akan meningkatkan jumlah makrofag bermigrasi ke area luka sehingga meningkatkan produksi growth factors yang akan menstimulasi peningkatan pembentukan pembuluh darah baru dan meningkatkan migrasi dan proliferasi fibroblas pada dasar luka (Kimura et al., 2006). Fibroblas akan menstimulasi mitosis sel epidermal sehingga memicu terjadinya keratinisasi. Disamping itu, penumpukan fibroblas pada dasar luka juga akan menstimulasi proses granulasi jaringan luka. Ketika granulasi dan keratinisasi terjadi, maka akan terbentuk lapisan barier penutup luka. Sebagai upaya mempercepat penutupan tersebut, maka fibroblas akan berubah menjadi myofibroblas yang mempunyai ikatan mikrofilamen aktin sehingga akan menimbulkan kontraksi pada luka dan luka akan cepat menutup (Falanga, 2003).

Lama waktu penyembuhan luka bakar derajat II dangkal pada kelompok ekstrak daun pegagan $25 \%$ yang dilakukan Widianingtyas et al. (2014) lebih cepat daripada penelitian ini dikarenakan jenis kelamin tikus yang digunakan pada penelitian Widianingtyas et al. (2014) adalah betina sedangkan pada penelitian ini berjenis kelamin jantan. Kadar hormon estrogen yang lebih tinggi pada tikus berjenis kelamin betina diduga menunjang peran ekstrak pegagan $25 \%$ dalam percepatan proses penyembuhan luka bakar. Lama waktu penyembuhan pada kelompok ekstrak daun petai cina $30 \%$ penelitian ini lebih cepat dibandingkan dengan hasil penelitian milik Rohmah et al. (2016) dikarenakan pada penelitian ini menggunakan ekstrak murni sedangkan pada penelitian Rohmah et al. (2016) menggunakan ekstrak kasar / gerusan daun petai cina. Diduga kandungan metabolit sekunder pada ekstrak murni daun petai cina lebih baik dibandingkan dengan ekstrak kasar sehingga lebih optimal dalam memberikan efek dalam penyembuhan luka bakar.

\section{SIMPULAN}

Pengobatan luka bakar dengan menggunakan ekstrak daun petai cina $30 \%$ lebih efektif daripada ekstrak daun 
pegagan $25 \%$ dalam penyembuhan luka bakar pada tikus putih (Rattus norvegicus) yang dibuktikan dengan waktu penyembuhan luka bakar yang paling cepat.

\section{DAFTAR PUSTAKA}

Bhavna, D., Jyoti, K., 2011. Centella Asiatica: The Elixir of Life. International Journal of Research in Ayurveda \& Pharmacy, pp.431-38.

Church, D., Elsayed, S., Reid, O., Winston, B., Lindsay, R., 2006. Burn Wound Infection. Clinical Microbiology Reviews, pp.403-34.

Depkes, 2013. Riset Kesehatan Dasar. Jakarta: Badan Penelitian dan Pengembangan Kesehatan Kementerian Kesehatan RI.

Dewantari, D.R., Suhartini, N., 2015. Formulasi dan Uji Aktivitas Gel Ekstrak Daun Petai China (Leucaena glauca, Benth) sebagai Sediaan Obat Luka Bakar. Farmasains, pp.217-22.

Falanga, V., 2003. Mechanisms of Cutaneous Wound Repair. In Fizpatrick's Dermatology in General Medicine. 6th ed. New York: GrawHill. pp.236-46.

Gomez, R., Murray., C.K., Hospenthal, D.R., Cancio, L.C., Renz, E.M., Holcomb, J.B., 2009. Causes of Mortality by Autopsy Findings of Combat Casualties and Civilian Patients Admitted to a Burn Unit. Journal of the American College of Surgeon, pp.348-54.

Lin, T.S., Azian, A.L., Srijit, D., 2010. Use of Traditional Herbal. Journal of Clinical Dermatology, pp.1-5.Majid, A., Prayogi, A.S., 2013. Perawatan Pasien Luka Bakar. Yogyakarta: Gosyen Publishing.

Moenadjat, Y., 2009. Luka Bakar Masalah dan Tata Laksana. Jakarta: Balai Penerbit FKUI.

Rahmawati, I., 2014. Perbedaan Efek Perawatan Luka Menggunakan Gerusan Daun Petai China (Leucaena Glauca, Benth) dan Povidon Iodine
$10 \%$ dalam Mempercepat Penyembuhan Luka Bersih pada Marmut (Cavia Porcellus). Jurnal Wiyata, pp.227-34.

Rohmah, S.N., Fuadah, D.Z., Girianto, P.W.R., 2016. Efektivitas Daun Petai China (Leucaena Leucocephala) dan Daun Jarak Pagar (Jatropha Curcas) Terhadap Proses Penyembuhan Luka Bakar Grade II pada Tikus Putih (Rattus Novergicus). Jurnal Ilmu Keperawatan, pp.20-33.

Sheridan, R.L., 2012. Burns: A Practical Approach To Immediate Treatment and Long Term Care. London: Manson Publishing.

Somboonwong, J., Kankaisre, M., Tantisira, B., Tantisira, M.H., 2012. Wound Healing Activities of Different Extracts of Centella Asiatica in Incission and Burn Wound Models: an Experimental Animal Study. BMC Complementary and Alternative Medicine, pp.103-09.

WHO, 2014. Burns. [Online] Available at: HYPERLINK

"http://www.who.int/mediacentre/fact sheet/fs365/en/"

http://www.who.int/mediacentre/fact sheet/fs365/en/\# [Accessed 11 December 2016].

Widianingtyas, D., Wihastuti, T.A., Setijowati, N., 2014. Pengaruh Perawatan dengan Ekstrak Daun Pegagan (Centella asiatica) dalam Mempercepat Penyembuhan Luka Bakar Derajat 2 Dangkal pada Tikus Putih (Rattus Norvegicus) Strain Wistar. Majalah Kesehatan FKUB, pp.223-27.

Widyantoro, O.B., Sugihartini, N., 2015. Uji Sifat Fisik dan Aktivitas Ekstrak Daun Petai China (Leucaena glauca, Benth) Dalam Berbagai Tipe Basis Salep Sebagai Obat Luka Bakar. Media Farmasi, 12(2), pp.186-98. 